\title{
Lysolipid-Inspired Amphiphilic Polymer Nanostructures: Implications for Drug Delivery
}

\author{
Hoang Nam Nguyen, Metwally Ezzat, and Chun-Jen Huang*
}

Hoang Nam Nguyen - Department of Biomedical Sciences \& Engineering, National Central University, Jhong-Li, Taoyuan 320, Tai-wan.

Metwally Ezzat - Department of Biomedical Sciences \& Engineering, National Central University, Jhong-Li, Taoyuan 320, Taiwan.

Chun-Jen Huang - Department of Chemical \& Materials Engineering, and NCU-Covestro Research Center, National Central Universi-ty, Jhong-Li, Taoyuan 320, Taiwan.

R\&D Center for Membrane Technology, Chung Yuan Christian University, 200 Chung Pei Rd., Chung-Li City 32023, Taiwan.

* Corresponding Author: Email: cjhuang@ncu.edu.tw

\section{Materials and Methods}

Triethylamine (TEA), diethyl ether (anhydrous), Methanol, Curcumin, 4,4'-azobis (4cyanovaleric acid) (ACVA) were purchased from Alfa Aesar. Deuterium oxide $\left(D_{2} O\right)$, chloroform-d $\left(\mathrm{CDCl}_{3}\right)$, phosphate buffer saline (PBS), N,N-dimethylaminoethyl methacrylate (DMAEMA), pyrene, n-octanol were obtained from Acros Organics, $\mathrm{N}$-octanol was dried in molecular sieves before use. 2-chloro-2-oxo-1,3,2-dioxaphospholane (COP), Tween 80, 2Cyano-2-propyl dodecyl trithiocarbonate were purchased from Sigma-Aldrich. Anhydrous acetonitrile (ACN), tetrahydrofuran (THF, anhydrous) were bought from TEDIA, Dulbecco's Modified Eagle Medium (DMEM), Fetal Bovine Serum (FBS), (3-(4, 5-dimethylthiazolyl-2)-2, 5diphenyltetrazolium bromide) (MTT) assay kit was purchased from ThermoFisher Scientific. NIH 3T3 fibroblasts were obtained from Bioresource Collection and Research Center (BCRC), 
Supporting Information

Taiwan. BFTC-905 bladder carcinoma cell lines were donated by prof. Lee's lab at NCU, Taiwan. Dialysis membranes (MWCO 3.5K) were purchased from Spectrum Laboratories Inc., USA, and hydrated in water before use. ${ }^{1} \mathrm{H}$ nuclear magnetic resonance $\left({ }^{1} \mathrm{H}\right.$ NMR) was recorded on a Varian-500 spectrophotometer (500 MHz), chemical shifts were reported in ppm relative to trimethylsilane (TMS) at $0 \mathrm{ppm}$. The following symbols were used to represent the multiplicity ( $\mathrm{s}=$ singlet, $\mathrm{d}=$ doublet, $\mathrm{t}=$ triplet, $\mathrm{m}=$ multiplet). ${ }^{13} \mathrm{C}$ NMR spectra were recorded on a Varian500 spectrophotometer (500 MHz). ${ }^{31}$ P NMR was recorded on a Bruker Advance-600 (700 $\mathrm{MHz}$ ). High-resolution mass spectra (HRMS) were measured by JEOL JMS-700 mass spectrophotometer. GPC measurements were obtained using water as the mobile phase and Polyethylene oxide (PEO) calibration standards, operating at $0.7 \mathrm{ml} / \mathrm{min}$ at $40{ }^{\circ} \mathrm{C}$ with $\mathrm{A} 3000$ Single-pore GPC/SEC column $(300 \times 8 \mathrm{~mm})$ and equipped with Viscotek RI detector [VE3580, Malvern]. The samples were filtered through a $0.45 \mu \mathrm{m}$ filter before analysis. Fluorescence spectra were used to measure the critical micelle concentration (CMC). The emission spectra were measured at $390 \mathrm{~nm}$, and the excitation spectra were recorded in the range of 300-400 $\mathrm{nm}$, with Both emission and excitation bandwidth was $5 \mathrm{~nm}$. The concentration of curcumin was determined using a UV-Vis spectrophotometer (V-630, JASCO). The particle size, size distribution, and $\zeta$-potential were measured using the dynamic light scattering (DLS) technique with a Malvern Zetasizer Nano-ZS instrument. Atomic Force Microscopy (AFM, JEOL JSPM-5200, JEOL) studies were performed in tapping mode under ambient conditions. AFM samples were prepared by applying $10 \mu \mathrm{L}$ sample drop into freshly cleaved mica, and the samples were dried in an ambient environment. Cryo-transmission electron microscopy (Cryo-TEM) studies were measured by (JEM-2000FXII) at magnification power of $10000 \mathrm{X}$ and the accelerating voltage of $200 \mathrm{kV}$.

Synthesis of 2-Octyloxy-2-oxo-1,3,2-dioxaphospholane; OOP 
Supporting Information

Anhydrous octanol (16 ml, $0.1 \mathrm{mmol}$ ) was added to $100 \mathrm{ml}$ anhydrous THF, followed by TEA $(14 \mathrm{ml}, 0.1 \mathrm{mmol})$. The solution was cooled $\left(-20\right.$ to $\left.-30^{\circ} \mathrm{C}\right)$, and COP was added slowly over 30 min using a dropping funnel. The mixture was stirred for an additional $1 \mathrm{~h}$ at this temperature, then the cooling bath was removed, and the mixture was allowed to stir for another 3 hours at room temperature. The resulting white suspension was filtered off using a vacuum pump under a nitrogen atmosphere. The filtrate was concentrated by rotary evaporator for 12 hours to produce OOP as a light yellow oil (yield 80-90\%).

${ }^{1} \mathrm{H}-\mathrm{NMR}\left(\delta: \mathrm{ppm}, 500 \mathrm{MHz}, \mathrm{CDCl}_{3}\right): 4.40-4.31(4 \mathrm{H}, \mathrm{ddd}), 4.12(2 \mathrm{H}, \mathrm{dd}), 1.67(2 \mathrm{H}, \mathrm{dt}), 1.33(2 \mathrm{H}$, $\mathrm{m}), 1.26(8 \mathrm{H}, \mathrm{m}), 0.84(3 \mathrm{H}, \mathrm{t})$ as shown in Fig. $\mathrm{S} 1,{ }^{13} \mathrm{C} \mathrm{NMR}\left(500 \mathrm{MHz}, \mathrm{CDCl}_{3}\right) \delta 77.27$ $\left(\mathrm{OPO} \underline{\mathbf{C}} \mathrm{H}_{2}\left(\mathrm{CH}_{2}\right)_{2}\right), 76.85\left(\mathrm{OPO}\left(\underline{\mathrm{C}} \mathrm{H}_{2}\right)_{2} \mathrm{O}\right), 31.79\left(\mathrm{CH}_{3} \mathrm{CH}_{2} \underline{\mathrm{C}} \mathrm{H}_{2} \mathrm{CH}_{2}\right), 30.91\left(\mathrm{OPOCH}{ }_{2} \mathrm{CH}_{2} \mathrm{CH}_{2}\right), 30.23$ $\left(\mathrm{CH}_{3}\left(\mathrm{CH}_{2}\right)_{2} \underline{\mathrm{C}} \mathrm{H}_{2}\right), 29.41\left(\mathrm{OPO}\left(\mathrm{CH}_{2}\right)_{3} \underline{\mathrm{C}} \mathrm{H}_{2}\right), 25.41\left(\mathrm{OPO}\left(\mathrm{CH}_{2}\right)_{2} \underline{\mathrm{CH}_{2}}\right), 22.64\left(\mathrm{CH}_{3} \underline{\mathrm{C}_{2}} \mathrm{CH}_{2}\right), 14.07$ $\left(\underline{\mathrm{C}} \mathrm{H}_{3} \mathrm{CH}_{2} \mathrm{CH}_{2}\right)$ as shown in Fig. S2, and ${ }^{31} \mathrm{P}-\mathrm{NMR}\left(\delta: \mathrm{ppm}, 700 \mathrm{MHz}, \mathrm{D}_{2} \mathrm{O}\right)$ with both ${ }^{1} \mathrm{H}$ coupling and decoupling: $17.6 \mathrm{ppm}$ as shown in Fig S3\&S4.

HRMS, m/z: $237.32(M+1 H)$, Fig S5.

Synthesis of 2-\{2-(Methacryloyloxy)ethyldimethylammonium\}ethyl n-octyl phosphate; MOP To a round-bottom flask containing anhydrous acetonitrile $(35 \mathrm{~mL})$, was added OOP $(2 \mathrm{M})$, followed by DMAEMA $(11.85 \mathrm{ml}, 2 \mathrm{M})$ at room temperature in glove box under nitrogen atmosphere. The mixture was stirred at $75{ }^{\circ} \mathrm{C}$ for 7 days. After the reaction had been completed, the mixture was cooled to room temperature and dissolved in diethyl ether, giving a white suspension upon stirring. The suspension was kept at $-20^{\circ} \mathrm{C}$ overnight to precipitate MOP. The top layer was decanted, and the residue was centrifuged for $5 \mathrm{~min}$ at $9000 \mathrm{rpm}$ and washed several times with diethyl ether by a mix-centrifuge-decant sequence to remove unreacted starting materials. The residue was dried in vacuo to yield a white powder as the product. (The reaction yield over the two steps was around 50-60 \%), see Scheme S1. 
Supporting Information

${ }^{1} \mathrm{H}-\mathrm{NMR}\left(\delta: \mathrm{ppm}, 500 \mathrm{MHz}, \mathrm{D}_{2} \mathrm{O}\right): 6.18(1 \mathrm{H}, \mathrm{d}), 5.75(1 \mathrm{H}, \mathrm{d}), 4.67(2 \mathrm{H}, \mathrm{dd}), 4.32(2 \mathrm{H}, \mathrm{dd}), 3.92$

$(2 \mathrm{H}, \mathrm{dd}), 3.88-3.78(4 \mathrm{H}, \mathrm{dd}), 3.31(6 \mathrm{H}, \mathrm{s}), 1.95(3 \mathrm{H}, \mathrm{s}), 1.35(2 \mathrm{H}, \mathrm{m}), 1.29(8 \mathrm{H}, \mathrm{m}), 0.87(3 \mathrm{H}, \mathrm{dd})$,

See Fig. S6, ${ }^{13} \mathrm{C}$ NMR $\left(500 \mathrm{MHz}, \mathrm{D}_{2} \mathrm{O}\right) \delta 167.85(\mathrm{O} \underline{\mathbf{C}}=\mathrm{O}), 135.24\left(\underline{\mathbf{C}}=\mathrm{CH}_{2}\right), 127.63\left(\mathrm{C}=\underline{\mathbf{C}} \mathrm{H}_{2}\right), 66.45$

$\left(\mathrm{OP}(\mathrm{O}) \mathrm{O} \underline{\mathrm{C}} \mathrm{H}_{2}\right), \quad 64.80 \quad\left(\mathrm{~N}_{\underline{C}} \mathrm{H}_{2}-\mathrm{CH}_{2}\right), \quad 63.55 \quad\left(\mathrm{NCH}_{2}-\underline{\mathrm{C}} \mathrm{H}_{2} \mathrm{OP}\right), \quad 59.09 \quad\left(\mathrm{OPCH}_{2} \mathrm{CH}_{2} \underline{\mathrm{CH}}_{2}\right), \quad 58.59$

$\left(\mathrm{NCH}_{2} \underline{\mathrm{C}} \mathrm{H}_{2} \mathrm{OC}=\mathrm{O}\right), \quad 52.46\left(\mathrm{~N}\left(\underline{\mathrm{C}} \mathrm{H}_{3}\right)_{2}\right), 31.53 \quad\left(\mathrm{CH}_{3} \mathrm{CH}_{2} \underline{\mathrm{CH}}_{2} \mathrm{CH}_{2}\right), 30.33\left(\mathrm{OPCH}_{2} \underline{\mathrm{C}} \mathrm{H}_{2} \mathrm{CH}_{2}\right), 28.91$

$\left(\mathrm{CH}_{3} \mathrm{CH}_{2} \mathrm{CH}_{2} \underline{\mathrm{C}} \mathrm{H}_{2}\right), 25.38\left(\mathrm{OPCH}_{2} \mathrm{CH}_{2} \mathrm{CH}_{2} \underline{\mathrm{C}} \mathrm{H}_{2}\right), 22.33\left(\mathrm{CH}_{3} \underline{\mathrm{C}} \mathrm{H}_{2} \mathrm{CH}_{2}\right), 17.55\left(\underline{\mathbf{C}} \mathrm{H}_{3} \mathrm{CH}_{2} \mathrm{CH}_{2}\right), 13.66$

$\left(\underline{\mathbf{C}} \mathrm{H}_{3} \mathrm{C}=\mathrm{CH}_{2}\right)$, Shown in Fig. S7, and ${ }^{31} \mathrm{P}-\mathrm{NMR}\left(\delta: \mathrm{ppm}, 700 \mathrm{MHz}, \mathrm{D}_{2} \mathrm{O}\right)$ with both ${ }^{1} \mathrm{H}$ coupling and decoupling: 17.6 ppm as shown in Fig S8 \& S9.

HRMS, m/z: $394.5(M+1 H)$, Fig S10.

\section{RAFT polymerization for MOP}

$10 \mathrm{ml}$ methanol/ DMSO (1:1) was purged with nitrogen for $1 \mathrm{~h}$. MOP monomer $(1 \mathrm{M})$, 2Cyano-2-propyl dodecyl trithiocarbonate (CTA), and 4,4'-azobis(4-cyanovaleric acid) (ACVA) at a CTA:ACVA molar ratio of 3:1 were dissolved in this solvent in glove box under nitrogen atmosphere, and the polymerization was achieved at ambient temperature in the glove box for 4 hours. Propagation was terminated by placing the reaction flask into liquid nitrogen and allowing the mixture to warm while open to the air. Anhydrous diethyl ether was added to get white suspension and maintained at $-20^{\circ} \mathrm{C}$ overnight. The resulting white precipitate was centrifuged and rinsed with diethyl ether several times and re-dissolved in water, then subjected to dialysis against water using a 3.5K MWCO membrane. After dialysis, the polymer was dried using freeze dryer, and the final product was obtained as a white powder.

\section{CMC determination}

To determine the critical micelle concentration for pMOP polymeric micelles, the pyrene fluorescence method was used. In brief, $5 \mathrm{mg}$ of pyrene was dissolved in $50 \mathrm{ml}$ acetone using sonication for $30 \mathrm{~min}$ (Stock solution). $10 \mu \mathrm{L}$ of this solution was added to vials and was dried 
under a stream of nitrogen. pMOP was prepared in different concentrations ranging from (1 $\mathrm{mg} / \mathrm{mL}$ to $0.0015 \mathrm{mg} / \mathrm{mL}$, and $3 \mathrm{~mL}$ was added to each vial to achieve a final concentration of pyrene of $1.5 \times 10^{-6} \mathrm{M}$. The solution was kept undisturbed for 24 hours, then fluorescence spectra were recorded using emission wavelength at $390 \mathrm{~nm}$, and the excitation spectra were recorded ranging from 300 to $400 \mathrm{~nm}$. The $\mathrm{CMC}$ concentration was calculated by plotting the fluorescence intensity against the logarithm of the concentration of pMOP.

\section{In vitro release study}

After drug loading, the in vitro drug release behavior was carried out at physiological temperature $\left(37^{\circ} \mathrm{C}\right)$ by directly immersing the dialysis tube into $5 \mathrm{~mL}$ of $\mathrm{PBS}(\mathrm{pH} 7.4)$ containing $0.5 \%$ of Tween 80 as releasing medium to keep the sink condition. The releasing medium containing curcumin was withdrawn and replaced with $5 \mathrm{~mL}$ of a fresh releasing medium at a predetermined time. The amount of curcumin released from the micelles was measured using a UV-vis spectrophotometer. The average value of the three independent experiments was collected, and the cumulative curcumin release was calculated as follows:

$$
\text { Curcumin Cumulative Release }(\%)=\frac{W t}{W i} .100
$$

Where $\mathrm{Wt}$ is the amount of curcumin released after the time $(\mathrm{t})$ and $\mathrm{Wi}$ is the initial amount of curcumin present in the micelle.

\section{Cytotoxicity study}

$\mathrm{NIH}-3 \mathrm{T3}$ and BFTC-905 cell lines were used to investigate the cytotoxicity of curcumin-loaded micelles, crude curcumin, or blank micelles using MTT assay. NIH-3T3 and BFTC-905 cells were incubated in DMEM (Dulbecco's minimum essential medium) medium with $10 \%$ FBS at $37^{\circ} \mathrm{C}$ in a humidified atmosphere containing 5\% CO2. After that, cells were harvested and seeded in a 96-well plate with a density of 5000 cells/well. After the incubation in $200 \mu \mathrm{L}$ of DMEM 
containing $10 \%$ FBS for $24 \mathrm{~h}$, a fixed amount of curcumin-loaded micelles or blank micelles with different concentrations dissolved in $200 \mu \mathrm{L}$ of DMEM or crude curcumin dissolved in DMEM containing $0.1 \%$ DMSO was added, and the cells were allowed to incubate for another $24 \mathrm{~h}$. After replacing the medium with $200 \mu \mathrm{L}$ of fresh DMEM, $20 \mu \mathrm{L}$ of MTT ( $5 \mathrm{mg} / \mathrm{mL}$ in PBS) solution was added to each well, and the cells were further incubated for $4 \mathrm{~h}$. Subsequently, the medium was removed, and $150 \mu \mathrm{L}$ of DMSO was added. After shaking at room temperature for several minutes, the optical density (OD) was measured at $570 \mathrm{~nm}$ with a microplate reader model 550 (Synergy HT, BioTek). The average value of three independent experiments was collected, and the cell viability was calculated as follows:

$$
\text { Cell viability }(\%)=\left(\frac{O D_{\text {sample }}}{O D_{\text {control }}}\right) \times 100
$$

Where OD sample was obtained for the cells treated with free curcumin, cur-loaded micelles, or blank micelles, and OD control was showed as the cells only treated with DMEM.
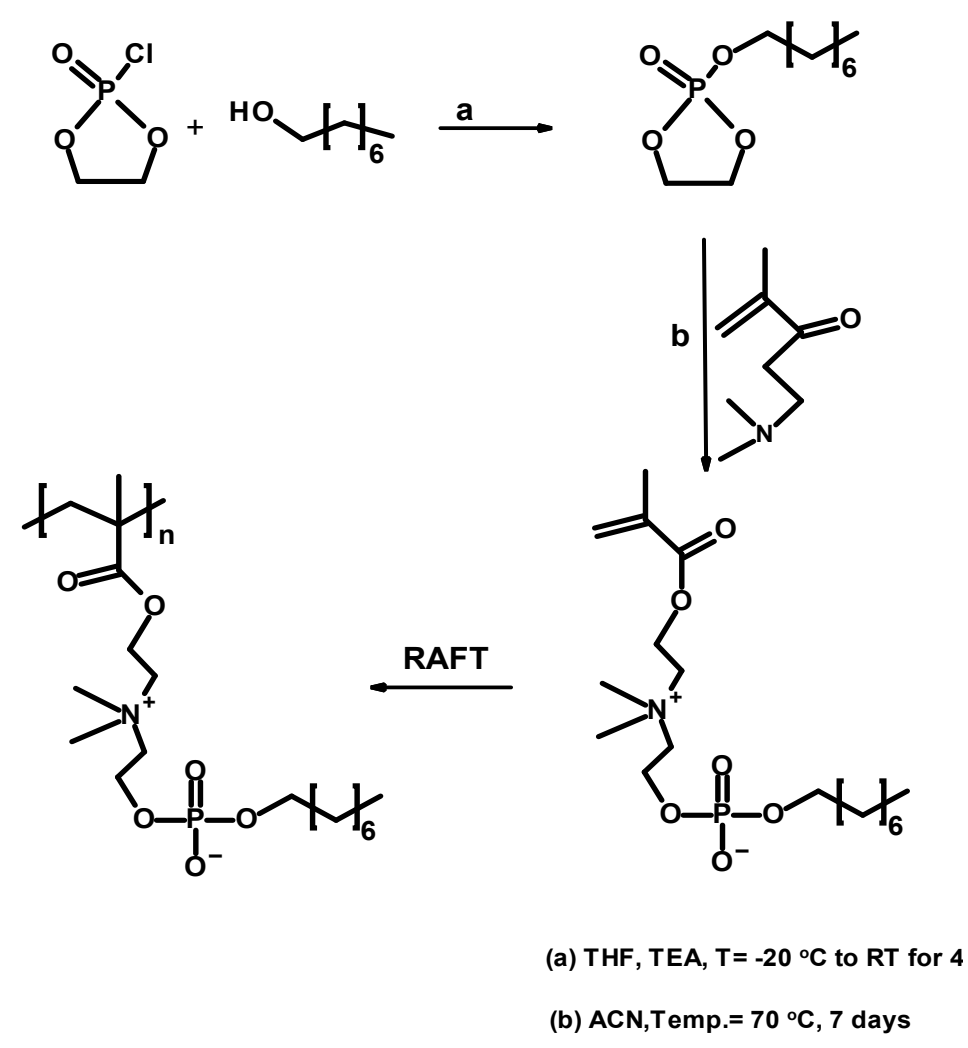
Scheme S1. The synthesis procedure of MOP monomer and its corresponding polymer (pMOP).

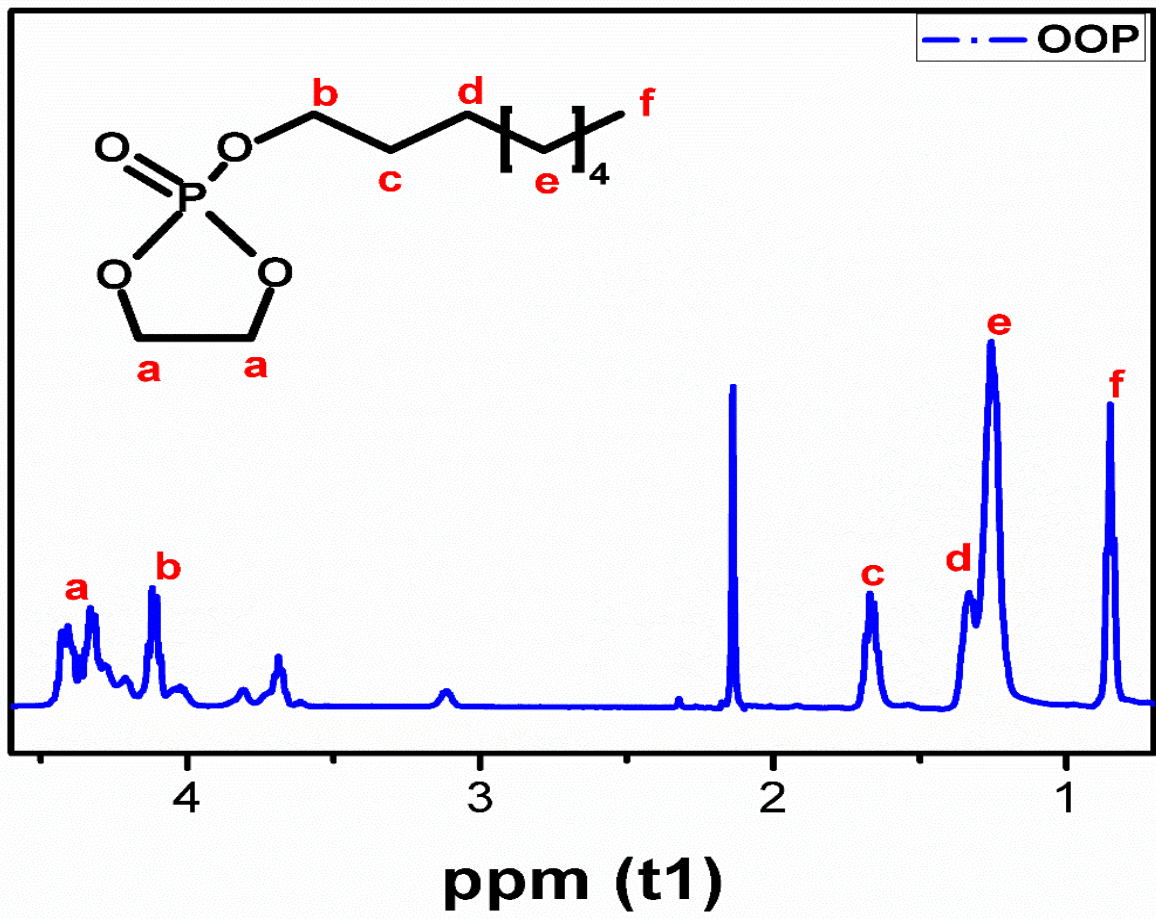

Figure S1. ${ }^{1} \mathrm{H}$ NMR spectra of OOP.

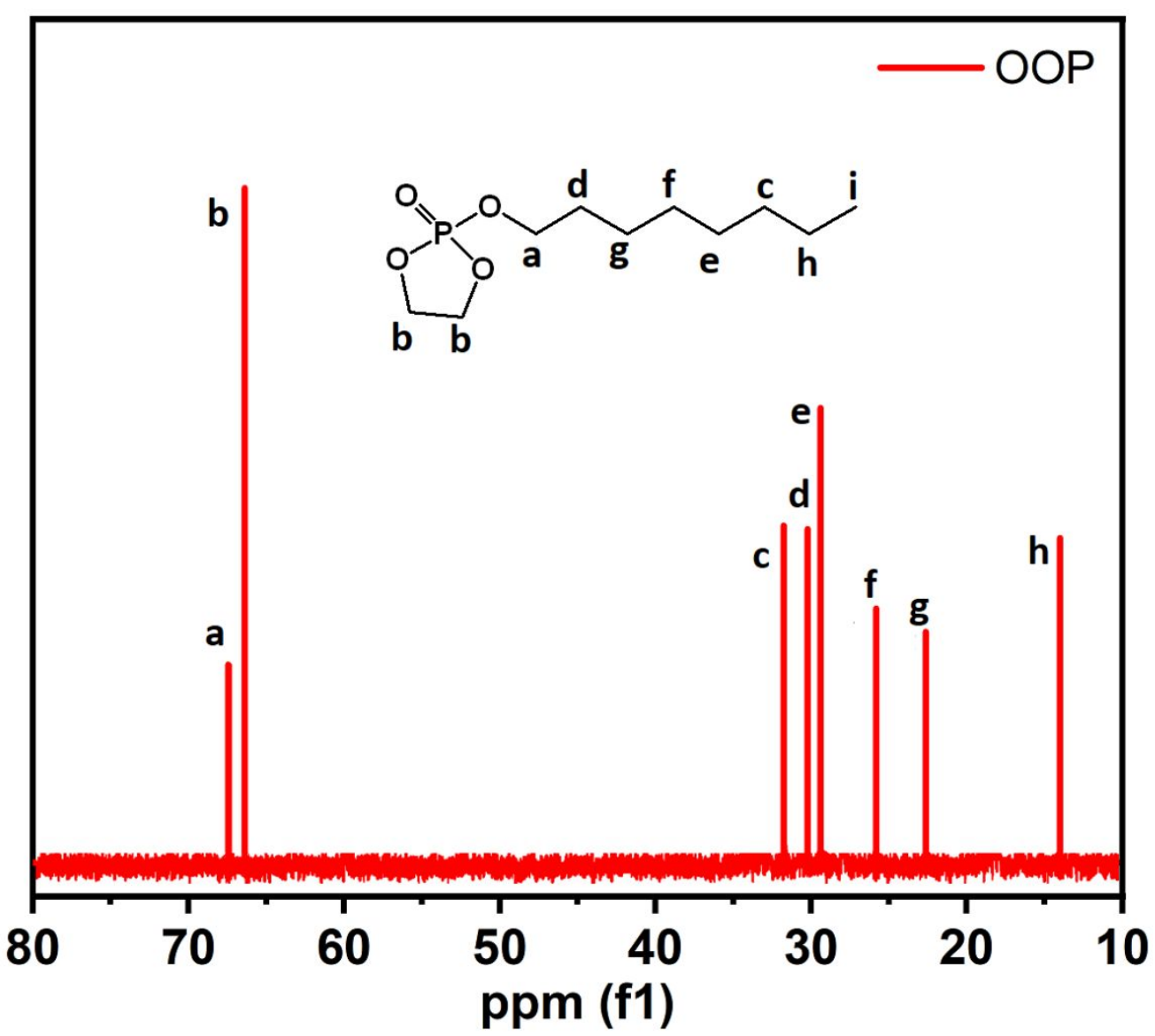


Figure S2. ${ }^{13} \mathrm{C}$ NMR spectra of OOP.

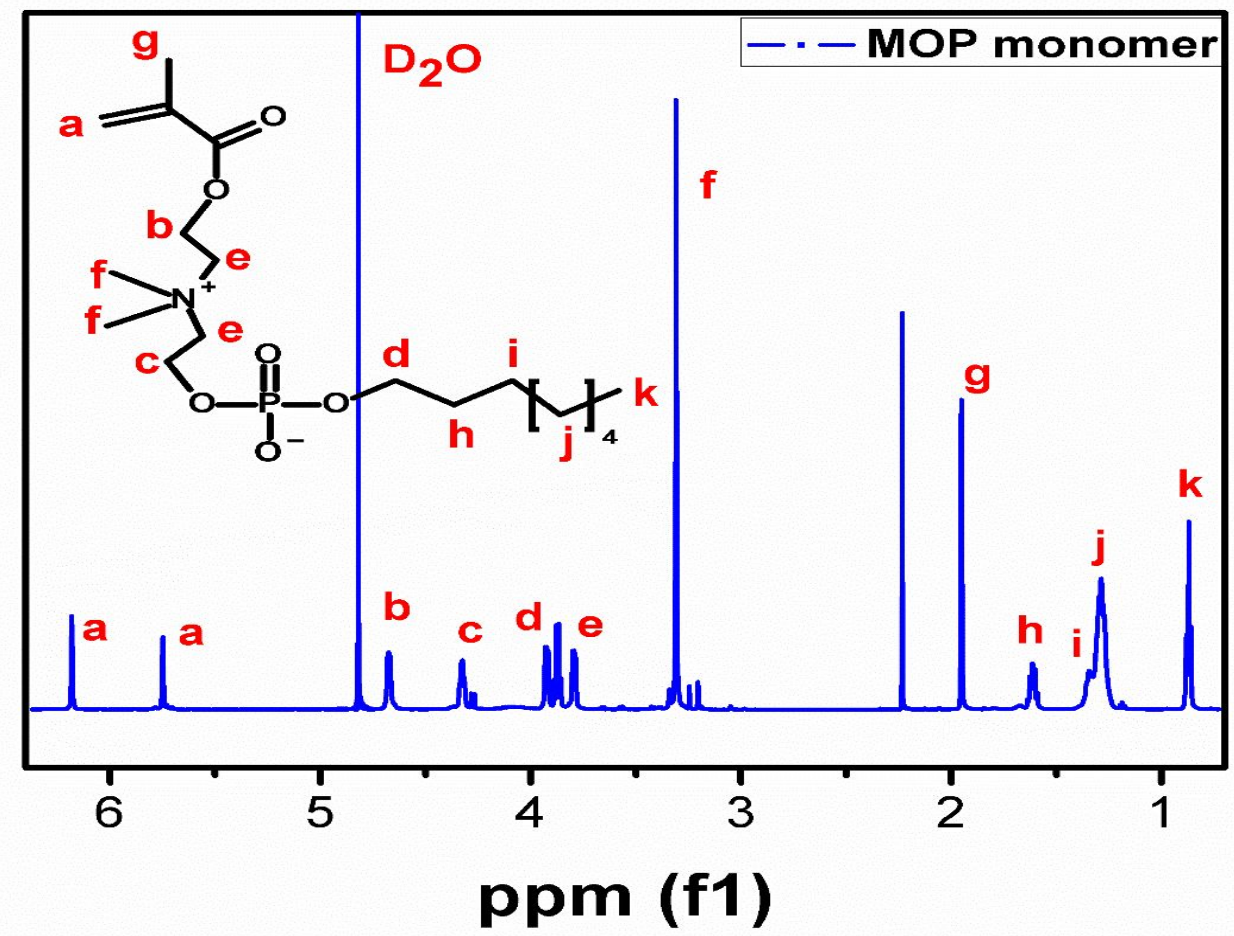

Figure S3. ${ }^{1} \mathrm{H}$ NMR spectra of MOP monomer.

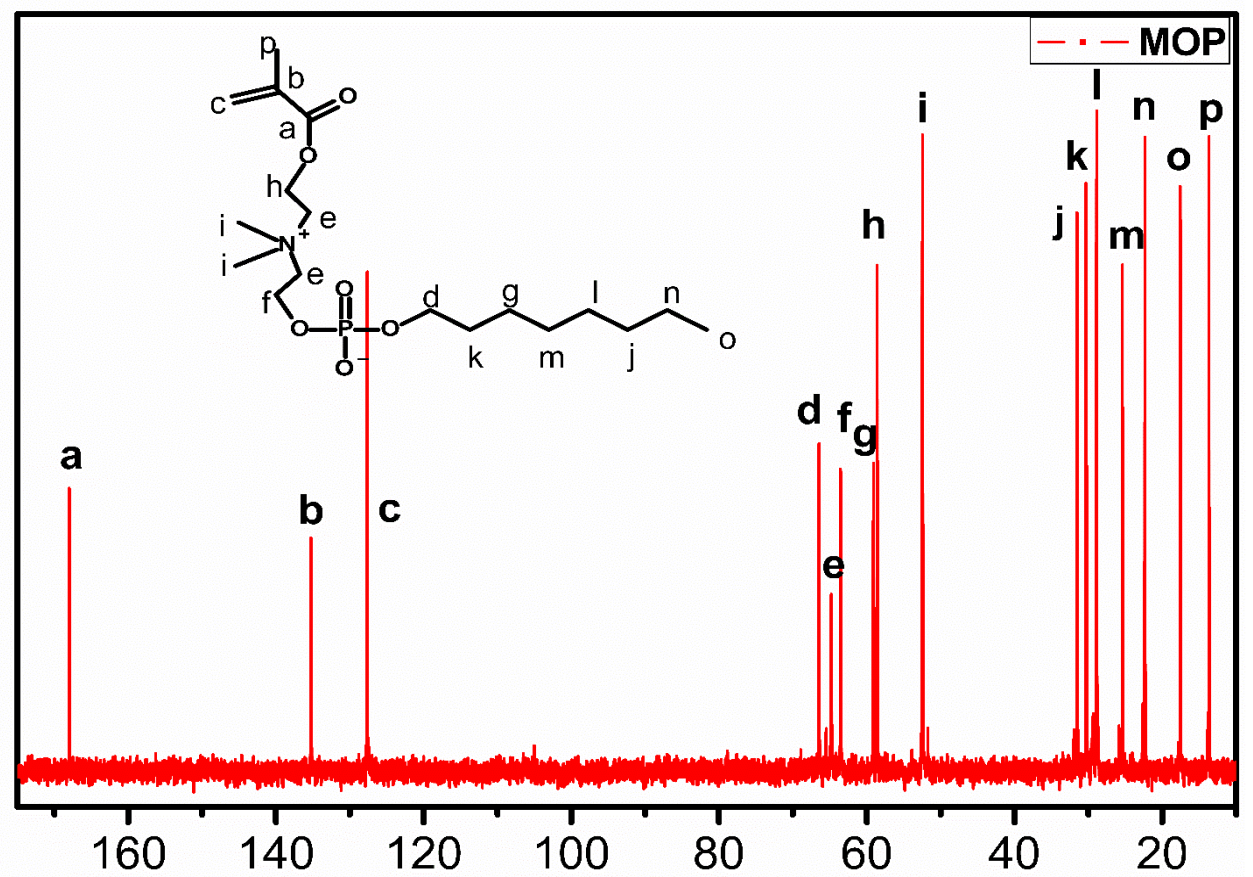

Figure S4. ${ }^{13} \mathrm{C}$ NMR spectra of MOP monomer. 


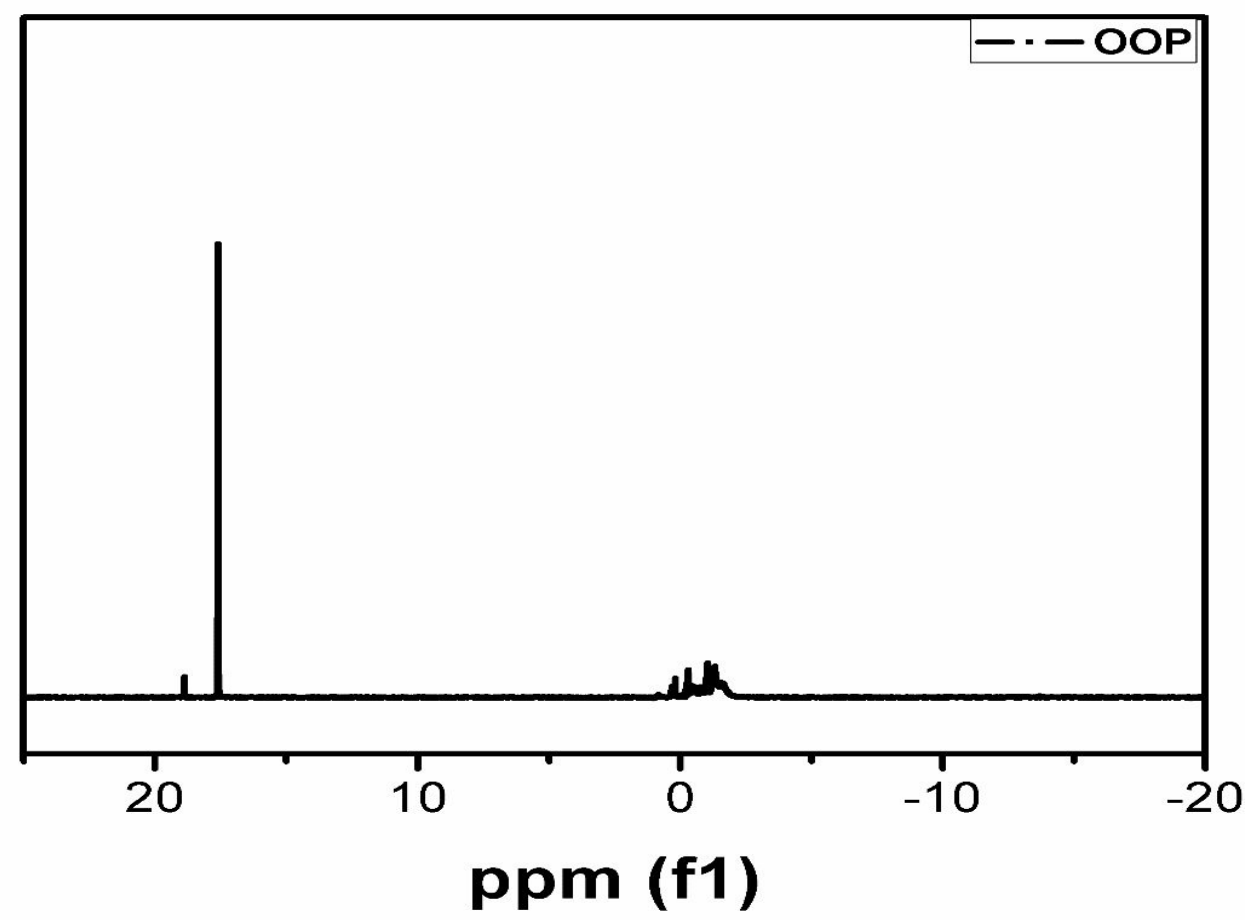

Figure S5. ${ }^{31} \mathrm{P}$ NMR spectrum for OOP with ${ }^{1} \mathrm{H}$ decoupling.

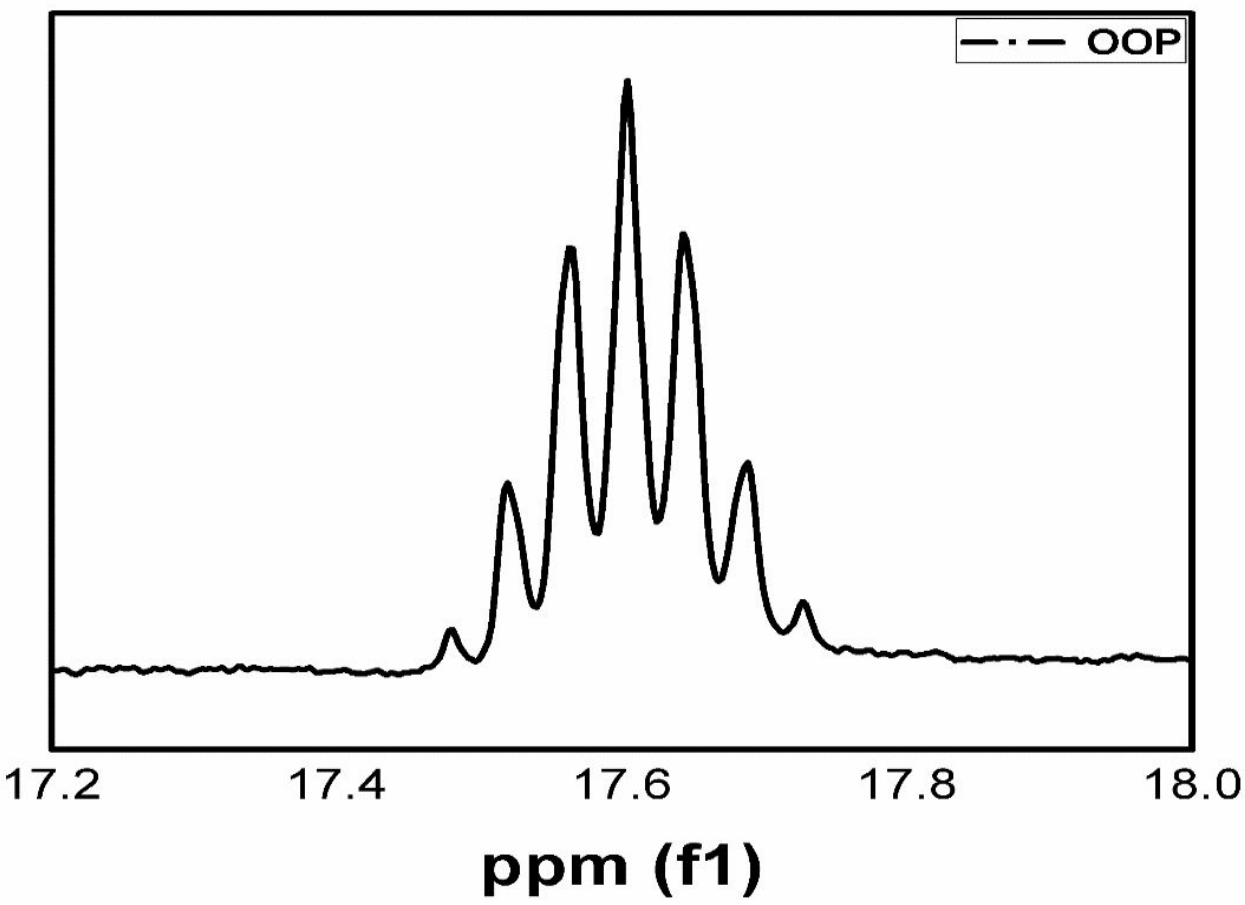

Figure S6. ${ }^{31} \mathrm{P} N M R$ spectrum for OOP with ${ }^{1} \mathrm{H}$ coupling. 


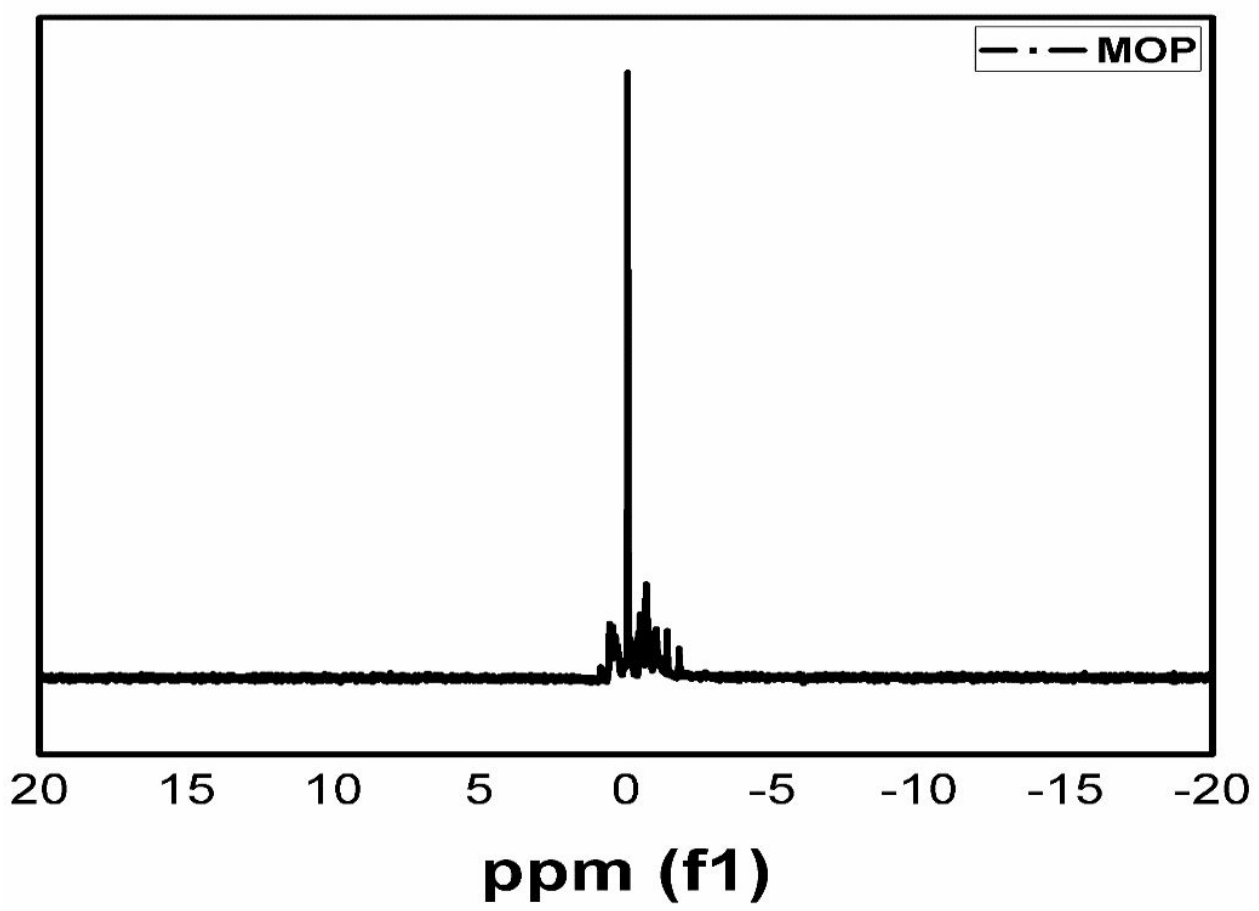

Figure S7. ${ }^{31} \mathrm{P}$ NMR spectrum for MOP with ${ }^{1} \mathrm{H}$ decoupling.

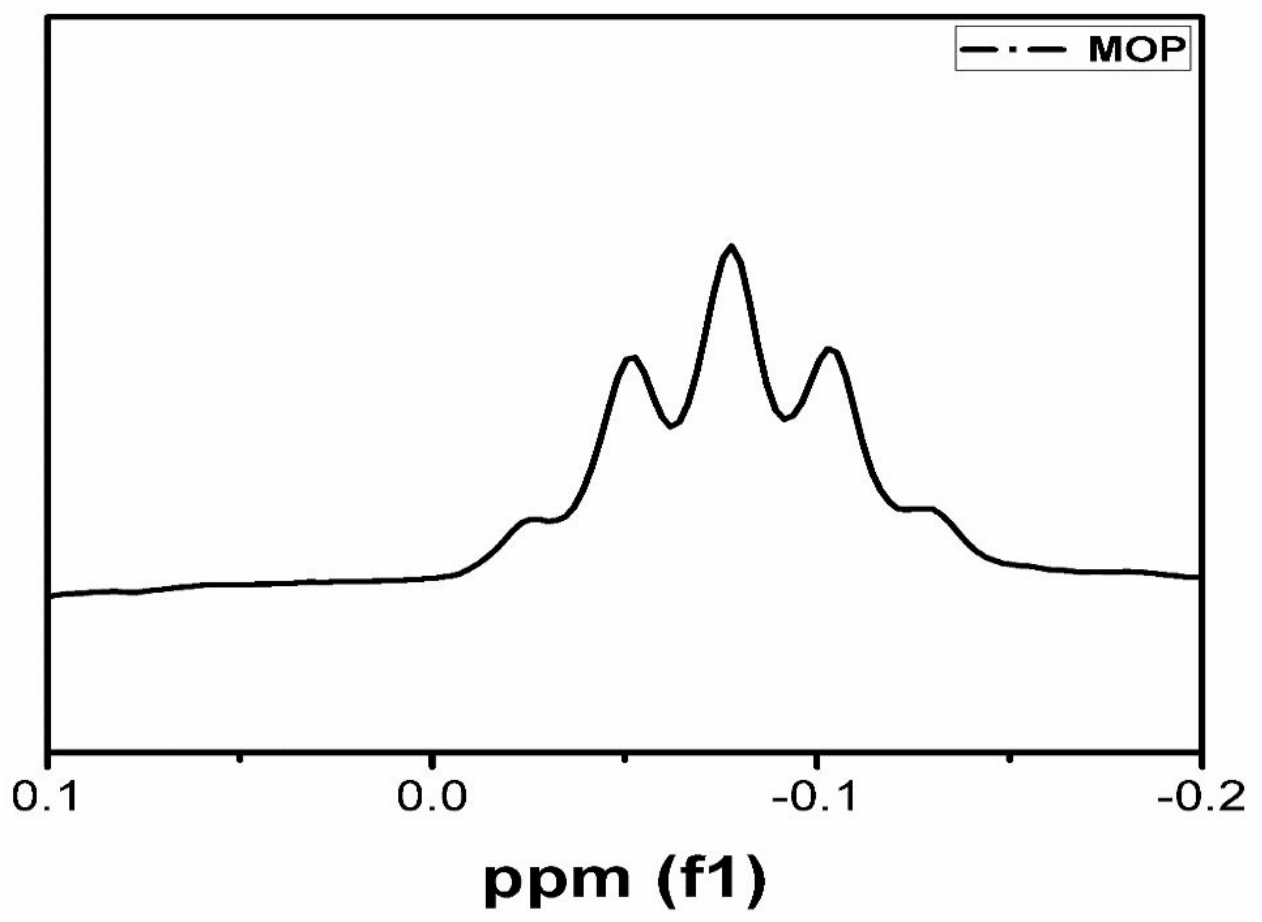

Figure S8. ${ }^{31} \mathrm{P} N M R$ spectrum for MOP with ${ }^{1} \mathrm{H}$ coupling. 


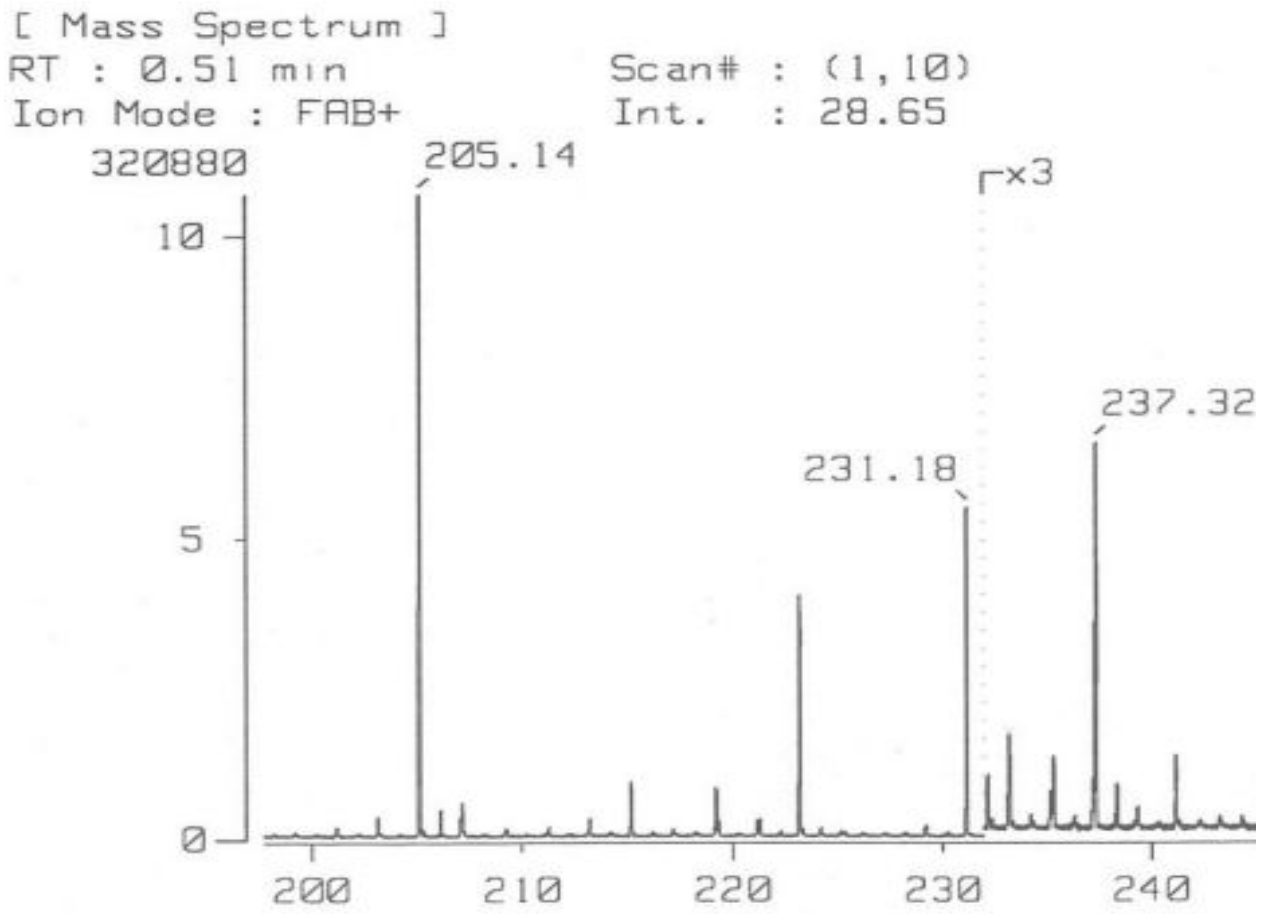

Figure S9. Mass spectra measurements of OOP.

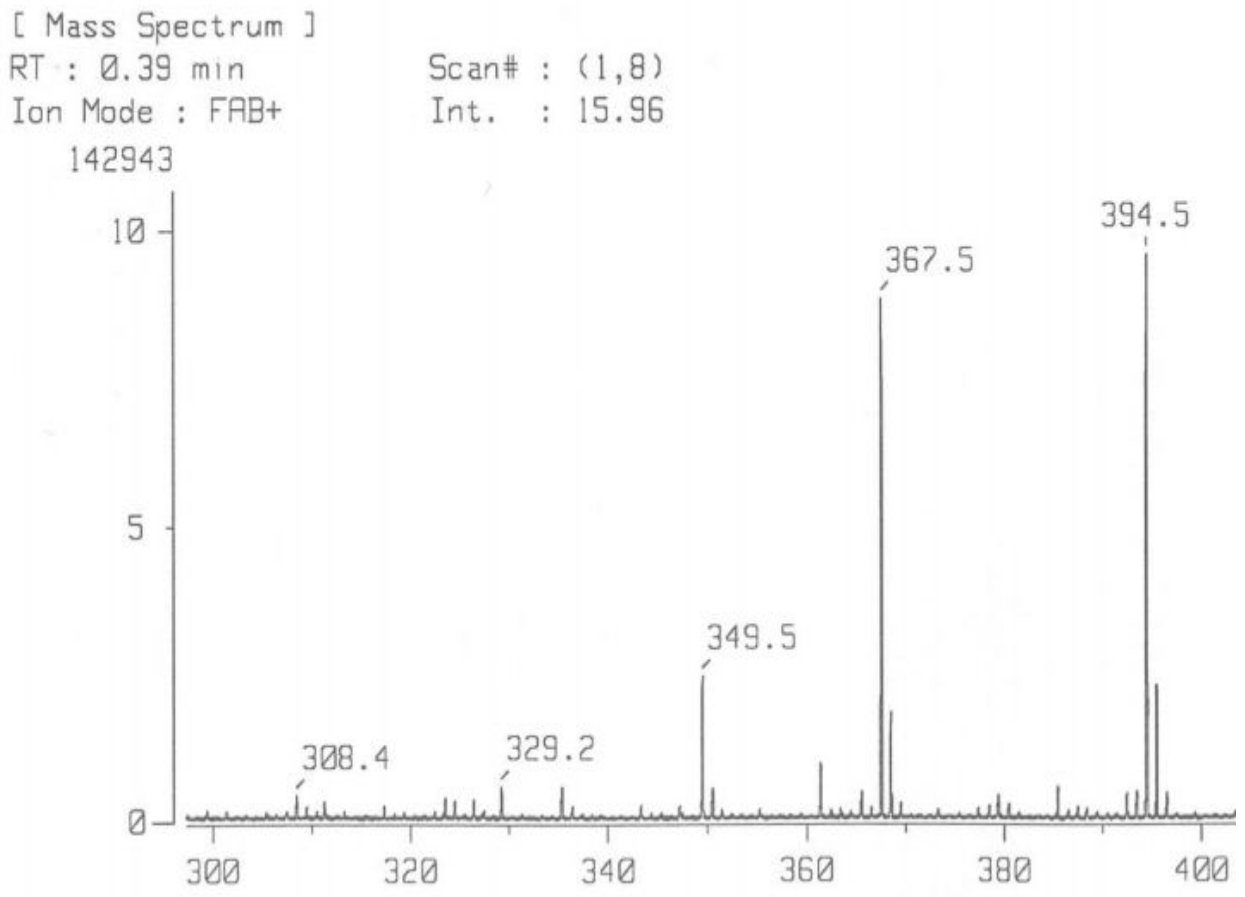

Figure S10. Mass spectra measurements of MOP monomer. 


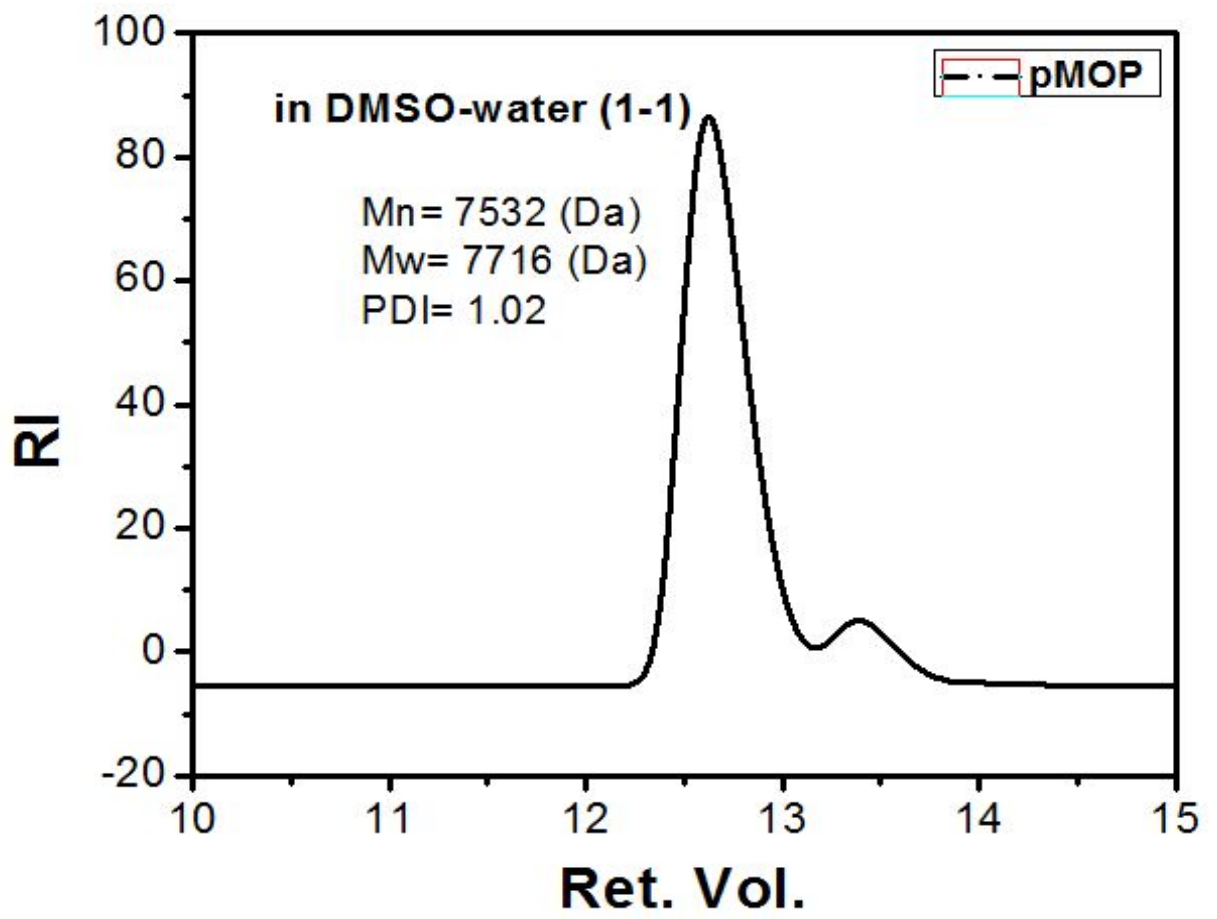

Figure S11. GPC measurement of pMOP.
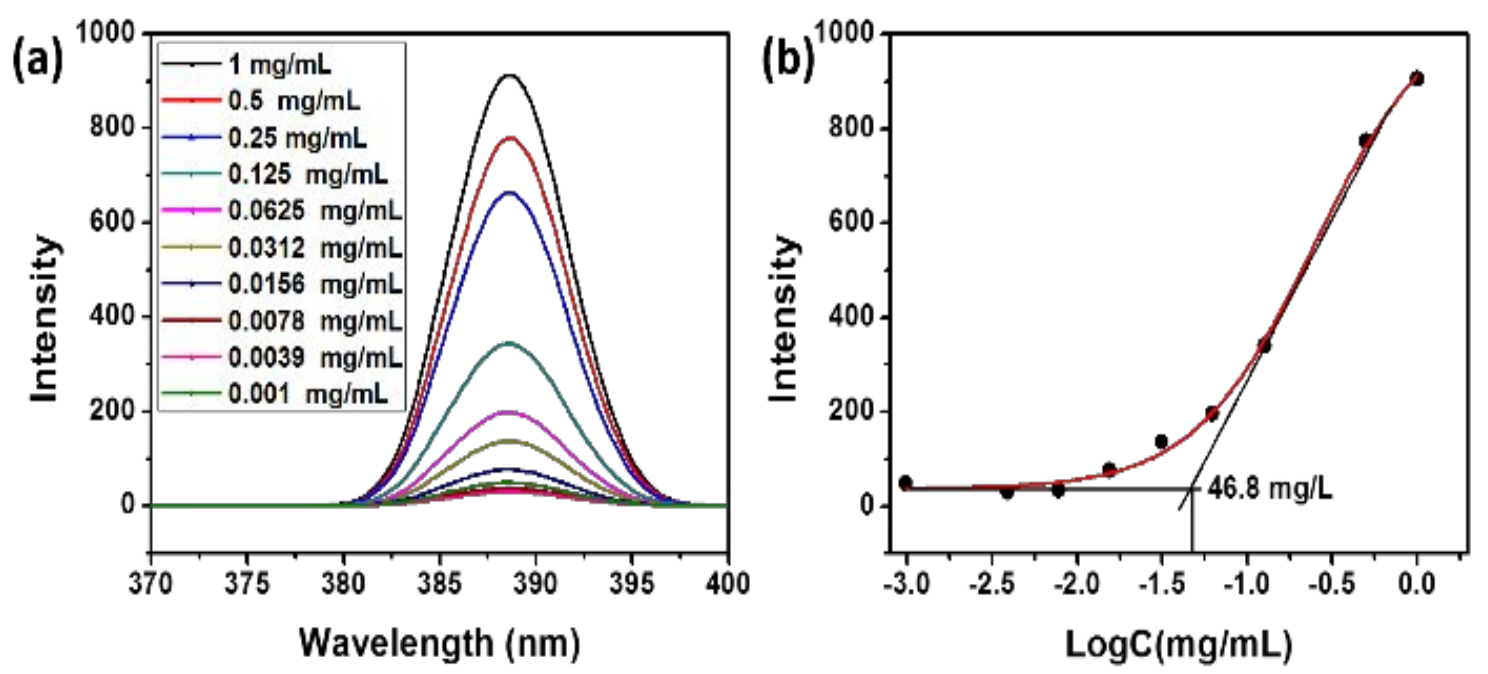

Figure S12. a) Fluorescence excitation spectra of pyrene in water containing pMOP micelles with different concentrations and (b) the intensity in the excitation spectra as a function of the logarithm of the concentration of pMOP micelles. 


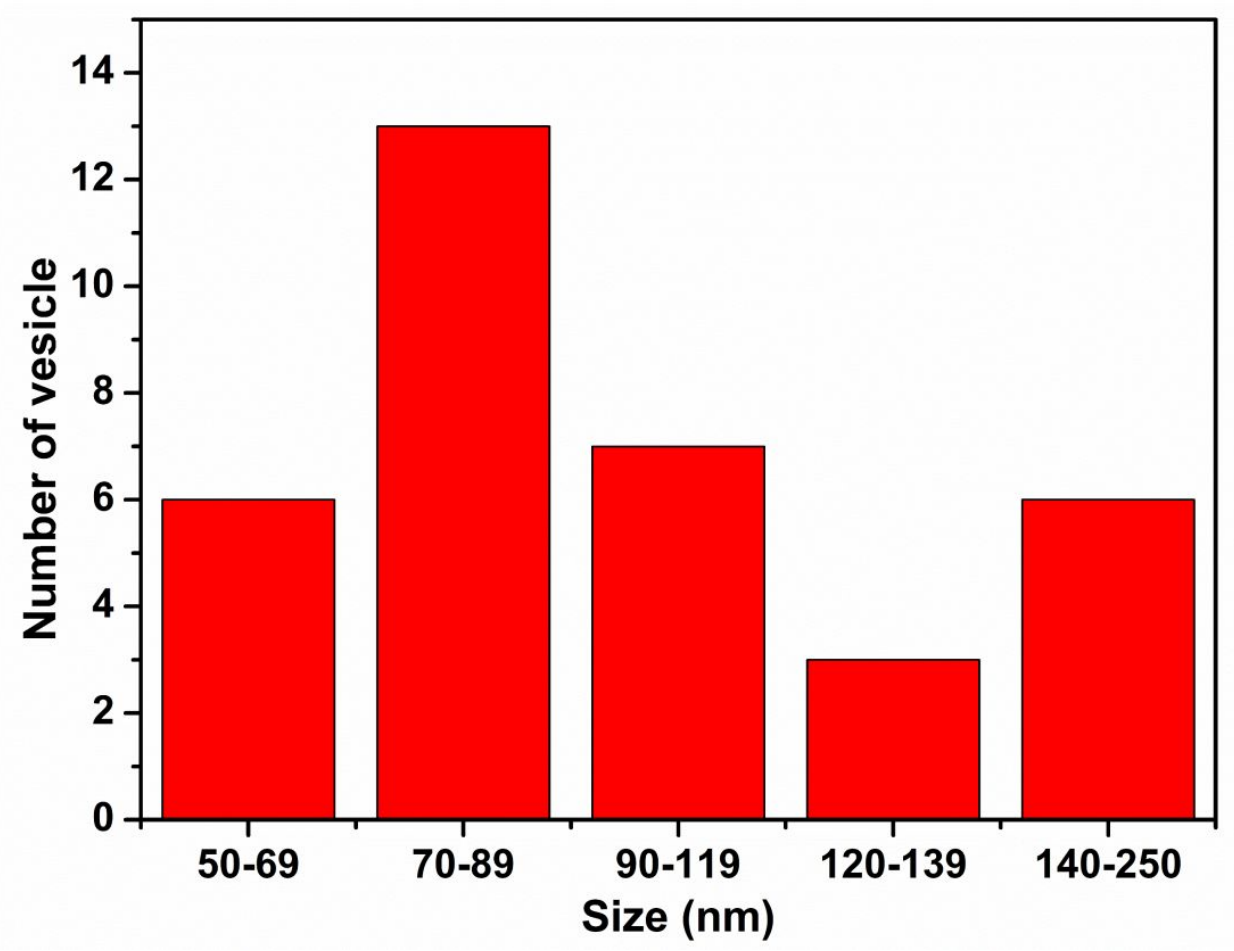

Figure S13. Size of pMOP-Cur micelles in water.

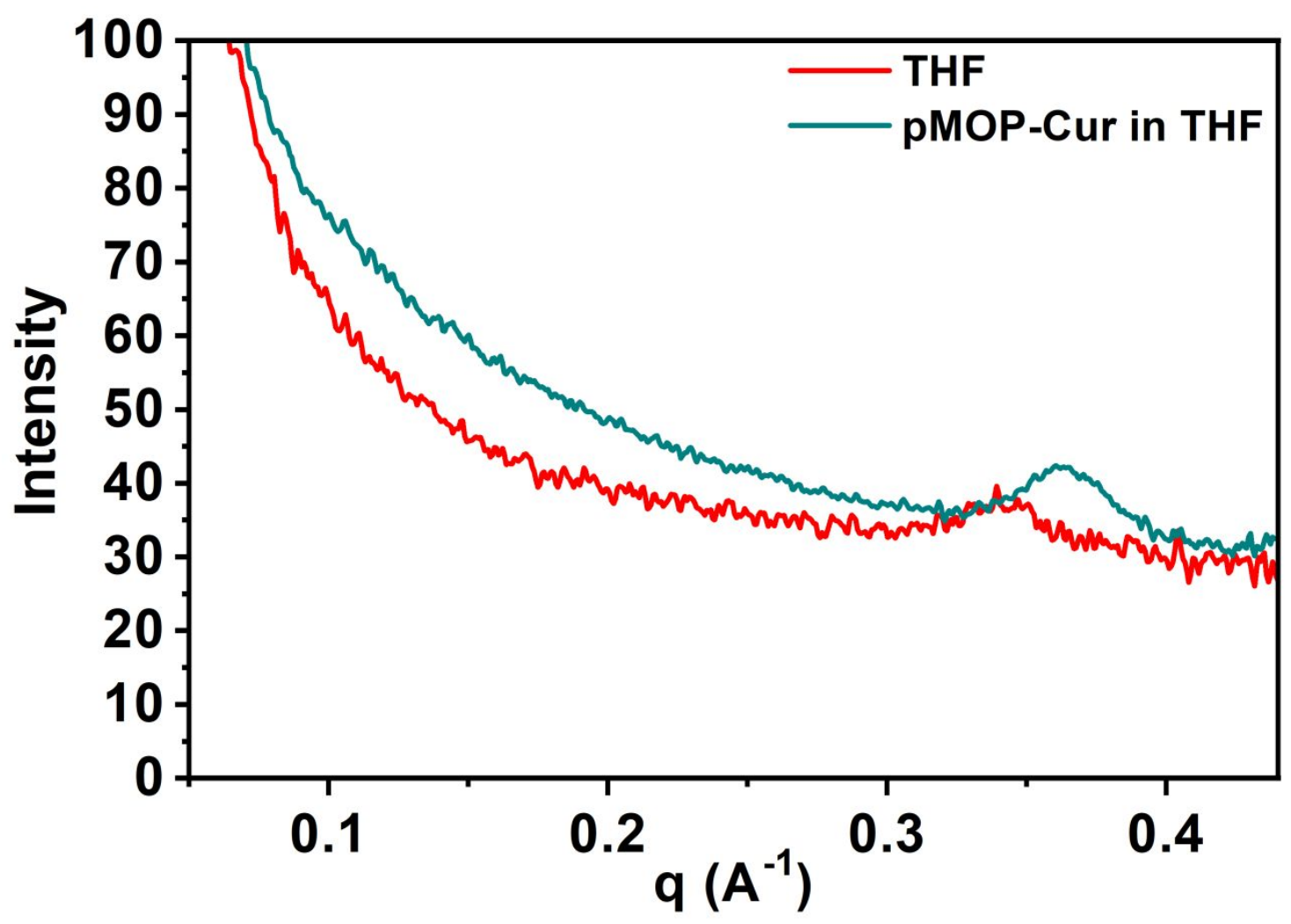

Figure S14. SAXS profile of THF and pMOP-Cur in THF. 


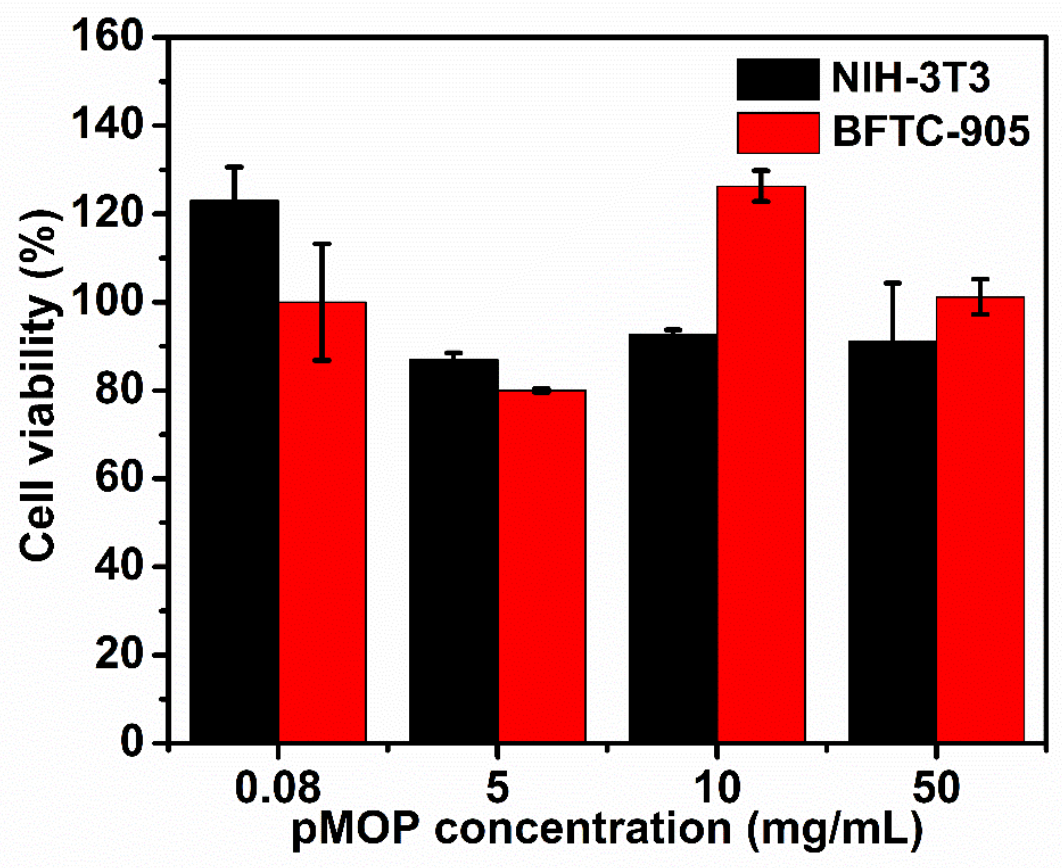

Figure S15. Cell viability of pMOP polymer on NIH-3T3 cells and BFTC-905 incubated for 24 $h(n=3)$. 